
\title{
28 Research Suare \\ Nitrous Oxide Emission from a Flooded Tropical Wetland across a Vegetation and Land Use Gradient
}

David Were ( $\Delta$ dwere51@gmail.com)

Makerere University College of Agricultural and Environmental Sciences https://orcid.org/0000-00034254-0614

Thomas Hein

BOKU: Universitat fur Bodenkultur Wien

\section{Research Article}

Keywords: Climate change, Greenhouse gases, N2O, Rice paddy, Uganda, Wetlands

Posted Date: August 31st, 2021

DOI: https://doi.org/10.21203/rs.3.rs-833228/v1

License: (c) (1) This work is licensed under a Creative Commons Attribution 4.0 International License. Read Full License 


\section{Abstract}

Whereas wetland ecosystems are among the most vital natural carbon sinks, they are also important sources of nitrous oxide $\left(\mathrm{N}_{2} \mathrm{O}\right)$, a highly potent greenhouse gas. However, due to differences in wetland characteristics, $\mathrm{N}_{2} \mathrm{O}$ emission is likely to vary across wetland types. We investigated the: 1) influence of vegetation community (Typha latifolia; Typha, Phragmites mauritianus; Phragmites and Cyperus papyrus; Papyrus) in a natural tropical freshwater wetland, and 2) impact of converting a natural tropical freshwater wetland into a rice paddy wetland on $\mathrm{N}_{2} \mathrm{O}$ emission. Results showed that $\mathrm{N}_{2} \mathrm{O}$ emission $(\mu \mathrm{g}$ $\left.\mathrm{m}^{-2} \mathrm{~h}^{-1}\right)$ from the natural wetland did not vary significantly $(p>0.05)$ among the vegetation communities during both the dry and wet seasons (Typha $=0.6 \pm 1.6$ [SE] and $0.5 \pm 1.4$, Phragmites $=0.5$ \pm 1.7 and $0.4 \pm 1.5$, Papyrus $=0.5 \pm 1.3$ and $0.5 \pm 1.5$, respectively). These emission rates insignificantly differed $(p>0.05)$ from those recorded in the rice paddy wetland (dry season $=0.7 \pm 2.8$ and wet season $=$ $0.6 \pm 2.7)$. There was no significant correlation $(p>0.05)$ between soil physico-chemical characteristics and $\mathrm{N}_{2} \mathrm{O}$ emission. We concluded that vegetation community does not affect $\mathrm{N}_{2} \mathrm{O}$ emission from a natural tropical freshwater wetland under continuous flooding. Similarly, under continuous flooding and no fertilization conditions, converting a natural tropical freshwater wetland into a rice paddy wetland does not influence $\mathrm{N}_{2} \mathrm{O}$ emission. We roughly estimated total annual $\mathrm{N}_{2} \mathrm{O}$ emissions $\left(\mathrm{T} \mathrm{yr}^{-1}\right.$ ) and their carbon dioxide equivalents $\left(\mathrm{CO}_{2} \mathrm{e} ; \mathrm{T} \mathrm{yr}^{-1}\right)$ from all Uganda's natural and rice paddy wetlands as: natural wetlands $=115.1 \pm 342.8(\mathrm{CO} e \mathrm{e}=30,501.5 \pm 90,842)$ and rice paddy wetlands $=0.9 \pm 2.7(\mathrm{CO} 2 \mathrm{e}=242.5 \pm$ 707.6).

\section{Introduction}

It is inevitable to conclude a conversation on global environmental concerns in the 21st Century without mentioning climate change, which science-based evidence attribute to the increasing emission and concentration of greenhouse gases (GHGs) in atmosphere. Addressing climate change and its impacts is currently no longer an option but a must if survival of humanity and ecosystems is to be sustained. According to the IPCC (2013), the main GHGs implicated in climate change are carbon dioxide $\left(\mathrm{CO}_{2}\right)$, methane $\left(\mathrm{CH}_{4}\right)$ and nitrous oxide $\left(\mathrm{N}_{2} \mathrm{O}\right)$, and account for close to $90 \%$ of the radiative forcing by long lived GHGs (WMO 2019). However, even though $\mathrm{N}_{2} \mathrm{O}$ has the lowest atmospheric concentration among the three GHGs, its global warming potential (GWP) is 265 times that of $\mathrm{CO}_{2}$, far higher than that of $\mathrm{CH}_{4}$, which is only 28 times that of $\mathrm{CO}_{2}$ on a 100-year timescale (IPCC 2014). This makes $\mathrm{N}_{2} \mathrm{O}$ an important greenhouse gas in the global climate change equation, and has since captured the attention of climate change scientists and policy makers worldwide.

Wetlands are recognized by the Millennium Ecosystem Assessment (2005) as vital ecosystems due to their various ecosystem services. Wetlands are among the most important natural ecosystems in climate change mitigation, while their services also help in adaptation to climate change impacts. Natural wetlands, in undisturbed state, are shown to be significant net carbon sinks, where their photosynthetic $\mathrm{CO}_{2}$ uptake through primary production exceeds $\mathrm{CO}_{2}$ loses due to ecosystem respiration (Mitsch et al. 
2013; Were et al. 2019). However, despite being carbon sinks, a number of studies indicate that wetlands are also important sources of $\mathrm{N}_{2} \mathrm{O}$ emitted into the atmosphere (Audet et al. 2014; Liengaard et al. 2013; Wu et al. 2009; Yang et al. 2019).

Unlike $\mathrm{CO}_{2}, \mathrm{~N}_{2} \mathrm{O}$ is primarily biogenic (IPCC 2007), with denitrifiers and nitrifiers being key players in the regulation of global sinks and sources of $\mathrm{N}_{2} \mathrm{O}$. Denitrification and nitrification in wetland soils, and the resultant $\mathrm{N}_{2} \mathrm{O}$ emission are affected by changes in environmental conditions, which can occur either naturally due to temporal (e.g. diurnal and seasonal) variations, or due to wetland management practices (Ajwang'Ondiek et al. 2021). Intermittent flooding and drying cycles, which are associated with wet and dry seasons respectively in natural wetlands or associated with soil and water management practices in managed wetlands such as rice paddies alter soil parameters which regulate denitrification and nitrification processes (Liengaard et al. 2013). These parameters will likely vary even further under future climate scenarios, which are expected to greatly alter temperature, rainfall and nutrient regimes (Tian et al. 2015). Besides, environmental conditions in wetlands also vary spatially since soil conditions, vegetation/plant cover, and soil and water management practices also change even at small spatial scales (Butterbach-Bahl et al. 2016). Consequently, $\mathrm{N}_{2} \mathrm{O}$ emission can also vary across small spatial scales, necessitating measurements in all wetlands situated across different climatic and geographic locations, and under different wetland management practices (especially in agricultural wetlands such as rice paddies).

Whereas there has been an increase in the knowledge of the sinks and sources of $\mathrm{N}_{2} \mathrm{O}$, the global $\mathrm{N}_{2} \mathrm{O}$ budget remains less understood (IPCC 2007; Liengaard et al. 2013). Tropical ecosystems are vital in understanding global $\mathrm{N}_{2} \mathrm{O}$ balance because several studies have indicated that the high productivity of these ecosystems is likely to translate into rates of accumulation, recycling, and loss of nitrogen far higher than those of temperate ecosystems (Hedin et al. 2009; Liengaard et al. 2013; Liu et al. 2020; Pärn et al. 2018). Further, with a coverage of about $30 \%$ of the global wetland area (Marín-Muñiz et al. 2015), tropical wetlands have present a considerably high influence on global atmospheric $\mathrm{N}_{2} \mathrm{O}$ budget. Despite these, studies on $\mathrm{N}_{2} \mathrm{O}$ emission from wetlands have mainly focused on temperate wetlands (Ajwang'Ondiek et al. 2021; Liengaard et al. 2013). This has limited a proper understanding of the biochemistry, controls and magnitudes of $\mathrm{N}_{2} \mathrm{O}$ emission from tropical wetlands, hence hindering their inclusion in climate models.

Indeed, recent studies by Butterbach-Bahl et al. (2016) and Boateng et al. (2017) have noted with concern, the reliance of field measurements and estimation of GHG fluxes from tropical wetlands using emission factors calibrated from temperate wetlands, despite differences in conditions between the two climate types. Further, with specific reference to Uganda, whereas a few studies have investigated controls and magnitudes of GHG fluxes from the countries wetlands (e.g. Were et al. 2021a, b), they have mainly focused on $\mathrm{CO}_{2}$ and $\mathrm{CH}_{4}$, at the expense of $\mathrm{N}_{2} \mathrm{O}$. 
In the aim of this study was to investigate: 1) the influence of different vegetation communities (Cyperus papyrus, Typha latifolia and Phragmites mauritianus) within the same natural tropical freshwater wetland on $\mathrm{N}_{2} \mathrm{O}$ emission, 2) the effect of converting a natural tropical freshwater wetland into a rice paddy wetland on $\mathrm{N}_{2} \mathrm{O}$ emission, and 3 ) the environmental parameters regulating $\mathrm{N} 20$ emission from natural freshwater and rice paddy wetlands in the tropics.

\section{Materials And Methods}

\subsection{Study Area}

This study was conducted on Naigombwa wetland, which forms part of the complex and interconnected wetland systems of the Lake Kyoga basin in Eastern Uganda (Fig. 1). This extensive wetland has natural and altered sections. Thus, based on land use, the wetland can be subdivided into two different wetland subcategories: natural wetland and rice paddy wetland.

The natural wetland exhibits unaltered hydrology and vegetation characteristics, and can be sub-divided into three different sections in view of the dominant vegetation communities that permanently cover the wetland i.e. Typha latifolia (Typha), Phragmites mauritianus (Phragmites) and Cyperus papyrus (Papyrus) sections. The Papyrus vegetation community occurs downstream of the Typha and Phragmites vegetation communities, and its morphology displays two growth forms; emergent and floating (Were et al. 2020a), unlike the Typha and Phragmites vegetation communities that grow only emergent.

The rice paddy wetland was previously part of the natural wetland, with similar conditions as described above for the natural wetland, before it was altered to enable cultivation of rice. Rice is cultivated on a seasonal basis because it relies on natural flooding, which itself is dependent on seasonal rainfall. The cultivation is done on smallholder scales, where rice is planted through broadcasting of rice seeds by hand into the fields or by transplanting rice seedlings from nursery beds into the main fields. There is no standard planting density, and therefore, plant density varies from field to field.

Surface and ground water level dynamics in these wetlands and their riparian areas have been described by Kayendeke et al. (2018). Seasonal flooding and drying cycles have been reported at wetland edges of the natural wetland in relation to the wet and dry seasons, respectively. However, wetland areas away from the edges are usually flooded throughout the year, but the flooding level varies seasonally. In the rice paddy wetland, intermittent flooding and drying cycles also occur with respect to the wet and dry seasons. However, compared to the natural wetland, both the flooding level and duration in the rice paddy wetland are manually regulated depending on the rice growth/cultivation stage. During the entire sampling course for this study, water was above the soil surface in both the natural and rice paddy wetlands, during both the dry and wet seasons. 
The study area temperature can generally be described as warm. Air temperature data for the study area during the sampling period was obtained from the Uganda National Meteorological Authority (UNMA), and a showed wet season air temperature of $21.3 \pm 0.2^{\circ} \mathrm{C}$ (mean \pm standard error; SE), in comparison to a mean of $23.4 \pm 0.1^{\circ} \mathrm{C}$ during the dry season.

\subsection{Gas Sampling and Analysis}

Soil-atmosphere $\mathrm{N}_{2} \mathrm{O}$ exchange was measured in each of the wetlands/vegetation communities described in Sect. 2.1. With respect to the Papyrus vegetation community, which has emergent and floating growth forms, the gas sampling design considered both growth forms. Gas samples were collected using steady state flux chambers (Minamikawa et al. 2015). The chamber technique is preferred, and has been widely applied in the measurement of gas fluxes from wetlands because it is less costly and allows for measurements at fine scales (Butterbach-Bahl et al. 2016).

Chamber lids included the following components: a thermometer to monitor internal air temperature, a vent tube to stabilize inside air pressure, and a gas sampling port, which allowed for manual extraction of the gas samples from chambers using a syringe and a needle (Minamikawa et al. 2015). Because of the strong solar radiation in the tropics that increases heating up of the chambers during daytime sampling, white-coloured chambers were used whose external surfaces were further covered with a reflective aluminium tape. Chamber bases were sunk up to $10 \mathrm{~cm}$ into the soil (Butterbach-Bahl et al. 2016), onto which chamber lids were firmly fixed to provide a gas tight enclosure. The headspace of the chambers had the following average dimensions: height $=25 \mathrm{~cm}$ and basal area $=490.63 \mathrm{~cm}^{2}$, amounting to a volume of $10 \mathrm{~L}$.

In each sampling quadrat, three chambers were deployed and sampled consecutively to increase the spatial representativeness (Butterbach-Bahl et al. 2016; Minamikawa et al. 2015). To minimize artificial gas ebullition associated with physical soil disturbance during gas sampling, wooden walking platforms were installed. The wooden walking platforms also eased movement during sampling in these usually waterlogged environments. However, for the floating growth form of the Papyrus vegetation community, it was realized that the walking platforms could not control shaking and artificial gas ebullition during sampling due to the suspended nature of the root mat over the water column. This occurrence was noticed from preliminary measurements that showed abnormally high gas concentrations. Consequently, the final sampling plan excluded the floating growth form of the Papyrus vegetation community.

Sampling was done over a six-month period, equally spread across the dry (February, March and April 2019) and the wet (August, September and October 2019) seasons. During each sampling event, the duration of gas sampling for each chamber was limited to 30 minutes, at intervals of 10 minutes i.e. 0 , 10, 20, and 30 minutes (Butterbach-Bahl et al. 2016). Further, prior to the start of each sampling event, ambient air samples outside the chamber were collected for quality control (Butterbach-Bahl et al. 2016). Gas samples in the chambers were collected using $60 \mathrm{ml}$ luer lockable syringes attached to needles. The collected gas samples were stored in $10 \mathrm{ml}$ glass vials under high pressure, after being evacuated using 
$40 \mathrm{ml}$ of the syringe gas volume. Vial tops were covered with parafilms to prevent contamination of samples prior to analysis. The frequency of sampling in each wetland/vegetation community was twice a month, on a fortnightly basis. As a result, the total number of gas samples collected for each season in each wetland/ vegetation community was 72 . Gas samples were analysed by gas chromatography (SRI 8610C gas chromatograph, USA), at the International Livestock Research Institute (ILRI) in Nairobi, Kenya.

Nitrous oxide $\left(\mathrm{N}_{2} \mathrm{O}\right)$ flux, $\mathrm{f}\left(\mu \mathrm{g} \mathrm{m}^{-2} \mathrm{~h}^{-1}\right)$ was calculated as in Eq. 1 (Butterbach-Bahl et al. 2011). $\mathrm{N}_{2} \mathrm{O}$ flux was computed as linear only if $R^{2} \geq 0.70$ (Rochette et al. 2008).

$f=S \times \frac{V c}{A c} \times \frac{M}{V m} \times \frac{273.15}{273.15+T} \times P \times 601$

where: $\mathrm{S}=$ slope $\left(\mathrm{ppbv} \mathrm{min}^{-1}\right), \mathrm{Vc}=$ volume of the chamber $\left(\mathrm{cm}^{3}\right), \mathrm{A}=$ basal area of the chamber $\left(\mathrm{cm}^{2}\right), \mathrm{M}$ $=$ molar weight of $\mathrm{N}_{2} \mathrm{O}$ (which is $28 \mathrm{~g} \mathrm{~mol}^{-1}$ ), $\mathrm{Mv}=$ molecular volume of $\mathrm{N}_{2} \mathrm{O}\left(\mathrm{m}^{3} \mathrm{~mol}^{-1}\right), \mathrm{T}$ is the average chamber temperature during sampling $\left({ }^{\circ} \mathrm{C}\right), \mathrm{P}=$ Pressure at the time of sampling (atm), and 60 is used to convert minutes to hour.

\subsection{Measurement of Environmental Parameters}

Environmental (soil and hydrological) parameters were measured during the sampling period. In each wetland/vegetation community, soil samples at top $(0-10 \mathrm{~cm})$ soil layer (Inglett et al. 2012) were collected, from which soil physico-chemical characteristics; salinity, $\mathrm{pH}$ and total nitrogen (TN) and organic carbon $(\mathrm{OC})$ were determined. Soil temperature was also measured insitu, using a digital soil thermometer. Soil moisture content was not investigated since the wetlands were under continuous flooding throughout the course of the sampling period.

Composite soil samples, that were obtained after mixing three samples in each sampling plot were placed in labelled ziploc bags and transported for analysis at the Soil Science Laboratory, Makerere University, Kampala, Uganda. Soil samples were air dried at room temperature in the laboratory for 21 days, ground and sieved through a $2 \mathrm{~mm}$ nylon sieve.

Soil OC was obtained from soil organic matter, following loss on ignition procedure and using Van Bemmelen's index of 0.58 as in Were et al. (2020a). Soil TN content was determined following the Kjeldahl digestion procedure. Soil $\mathrm{pH}$ and salinity were obtained determined using a portable multiparameter meter (CyberScan PC 300), after mixing soil and deionized water using a soil : water ratio of 1 : 5 (Were et al. 2021a, b).

The wetland hydrological parameter considered in this study was water level, and specifically surface water level since water was above the soil surface for the entire sampling period. Surface water levels in the wetlands/vegetation communities were measured at the gas sampling location during each sampling event, using a cm-marked wooden stick.

\subsection{Data Analysis}


Data was sorted, and statistically analysed using the Microsoft Excel (2016) and R programming software (version 4.0.5). The data was first tested for normal distribution and homogeneity of variance. Whereas soil and surface water level data showed normal distribution, $\mathrm{N}_{2} \mathrm{O}$ flux data did not satisfy conditions for normal distribution. Consequently, parametric one-way ANOVA, alongside the Tukey HSD post-hoc tests were used to examine the significance of mean values of soil and water level characteristics between the wetlands/vegetation communities and seasons, at $p<0.05$ significance. On the hand, Kruskal-Wallis $\mathrm{H}$ test was used to test the significance of mean $\mathrm{N}_{2} \mathrm{O}$ fluxes between the wetlands/vegetation communities and seasons, at $p<0.05$ significance. The effect of environmental conditions on $\mathrm{N}_{2} \mathrm{O}$ fluxes was investigated by determining the Spearman's rank-order correlations between soil and surface water level characteristics and $\mathrm{N}_{2} \mathrm{O}$ flux, at $\mathrm{p}<0.05$ significance. Unless stated otherwise, all values are presented as mean \pm standard error (SE).

\section{Results}

\subsection{Soil Physico-chemical and Water Level Characteristics}

Soil physico-chemical characteristics did not vary significantly either between the wetlands/among vegetation communities or between seasons, except OC and C: $\mathrm{N}$ ratio (Table 1). Whereas mean OC contents of the three vegetation communities did not differ significantly $(p>0.05)$ during both the dry and wet seasons, they were over 2-fold higher compared to the rice paddy wetland. Mean C:N ratios of the Typha vegetation community (dry season $=33.2: 1$ and wet season $=33.3: 1)$ were significantly higher $(p<$ 0.05 ) than those measured in the other two vegetation communities of the natural wetland and rice paddy wetland. Mean $\mathrm{pH}$ values during the wet and dry seasons in both wetlands were slightly acidic, ranging from 5.98-6.54 and 6.00-6.87 during the wet and dry seasons, respectively. Temperature had mean values in both wetlands ranging from $26.3-26.9$ and $26.6-27.0$, with respect to the wet and dry seasons.

Water was above the soil surface even during the dry season, and rapidly increased significantly during the wet season (Fig. 2). Comparing the two wetlands, surface water levels in the three vegetation communities of the natural wetland during the dry season (Typha $=7.1 \pm 5.0 \mathrm{~cm}$ Phragmites $1.9 \pm 1.3=$ $\mathrm{cm}$ and Papyrus $=7.5 \pm 5.5 \mathrm{~cm}$ ) and wet season (Typha $=29.1 \pm 6.0 \mathrm{~cm}$, Phragmites $=21.0 \pm 5.2 \mathrm{~cm}$ and Papyrus $=31.5 \pm 6.1 \mathrm{~cm})$ were significantly higher $(p<0.05)$ than those recorded in the rice paddy wetland (dry season $=0.4 \pm 0.1 \mathrm{~cm}$ and wet season $=10.9 \pm 1.7 \mathrm{~cm}$ ). 
Table 1

Soil physico-chemical characteristics in the natural and rice paddy wetlands $(\mathrm{n}=36)$

\begin{tabular}{|c|c|c|c|}
\hline Soil/ hydrological Parameter & Wetland & Season & \\
\hline \multirow[t]{5}{*}{$\mathrm{pH}$} & Natural & Dry & Wet \\
\hline & Typha & $6.23 \pm 0.01$ & $6.24 \pm 0.02$ \\
\hline & Phragmites & $6.06 \pm 0.01$ & $6.20 \pm 0.01$ \\
\hline & Papyrus & $6.00 \pm 0.01$ & $5.98 \pm 0.01$ \\
\hline & Rice paddy & $6.87 \pm 0.03$ & $6.54 \pm 0.02$ \\
\hline \multirow[t]{5}{*}{ Temperature $\left({ }^{\circ} \mathrm{C}\right)$} & Natural & & \\
\hline & Typha & $26.9 \pm 0.1$ & $26.8 \pm 0.1$ \\
\hline & Phragmites & $26.6 \pm 0.1$ & $26.5 \pm 0.1$ \\
\hline & Papyrus & $26.6 \pm 0.0$ & $26.3 \pm 0.0$ \\
\hline & Rice paddy & $27.0 \pm 0.1$ & $26.9 \pm 0.1$ \\
\hline \multirow[t]{5}{*}{ TN (\%) } & Natural & & \\
\hline & Typha & $0.4 \pm 0.0$ & $0.4 \pm 0.0$ \\
\hline & Phragmites & $0.5 \pm 0.0$ & $0.5 \pm 0.0$ \\
\hline & Papyrus & $0.7 \pm 0.0$ & $0.8 \pm 0.0$ \\
\hline & Rice paddy & $0.4 \pm 0.0$ & $0.4 \pm 0.0$ \\
\hline \multirow[t]{5}{*}{$\mathrm{OC}(\%)$} & Natural & & \\
\hline & Typha & $12.9 \pm 0.1$ & $13.3 \pm 0.2$ \\
\hline & Phragmites & $12.1 .0 \pm 0.1$ & $12.7 \pm 0.1$ \\
\hline & Papyrus & $15.0 \pm 0.1$ & $16.3 \pm 0.0$ \\
\hline & Rice paddy & $6.00 \pm 0.1^{\star}$ & $6.2 \pm 0.0^{*}$ \\
\hline \multirow[t]{5}{*}{$\mathrm{C}: \mathrm{N}$} & Natural & & \\
\hline & Typha & $32.3 \pm 0.0^{\star}$ & $33.3: 1 \pm 0.0 *$ \\
\hline & Phragmites & $20.0 \pm 0.0$ & $23.4 \pm 0.0$ \\
\hline & Papyrus & $21.4 \pm 0.0$ & $20.4 \pm 0.0$ \\
\hline & Rice paddy & $20.0 \pm 0.0$ & $21.7 \pm 0.0$ \\
\hline Salinity $\left(\mathrm{mS} \mathrm{m}^{-1}\right)$ & Natural & & \\
\hline
\end{tabular}




\begin{tabular}{|llll|}
\hline Soil/ hydrological Parameter & Wetland & Season & \\
\hline Typha & $129.2 \pm 2.4$ & $125.9 \pm 1.7$ \\
\hline Phragmites & $118.6 \pm 2.5$ & $91.3 \pm 1.4$ \\
\hline Papyrus & $132.8 \pm 4.9$ & $128.7 \pm 3.8$ \\
\hline Rice paddy & $102.9 \pm 5.8$ & $91.1 \pm 2.2$ \\
\hline
\end{tabular}

*Significant $(p<0.05)$ within the same season, OC = Organic carbon, TN = Total nitrogen

\subsection{Nitrous Oxide Emission}

Generally, fluxes of $\mathrm{N}_{2} \mathrm{O}$ from both the natural and rice paddy wetlands were very low (close to zero) during the two sampling seasons. Considering the impact of vegetation community (in the natural wetland) on $\mathrm{N}_{2} \mathrm{O}$ fluxes, no significantly variation $(p>0.05)$ in $\mathrm{N}_{2} \mathrm{O}$ flux was noted among the three vegetation communities during both seasons (Table 2). Mean $\mathrm{N}_{2} \mathrm{O}$ fluxes from the three vegetation communities of the natural wetland ranged from $0.5-0.6 \mu \mathrm{g} \mathrm{m}^{-2} \mathrm{~h}^{-1}$ during the dry season, and from 0.4 $-0.5 \mu \mathrm{g} \mathrm{m}^{-2} \mathrm{~h}^{-1}$ during the wet season.

In view of the impact of land use change (from natural to rice paddy wetland) on $\mathrm{N}_{2} \mathrm{O}$ fluxes, the difference between $\mathrm{N}_{2} \mathrm{O}$ fluxes from the natural and rice paddy wetlands was insignificant $(p>0.05)$, with the latter recording mean flux values of 0.7 and $0.6 \mu \mathrm{g} \mathrm{m}^{-2} \mathrm{~h}^{-1}$ during the dry and wet seasons, respectively. Further, in both wetlands, seasonal changes (dry vs wet) did not affect $\mathrm{N}_{2} \mathrm{O}$ fluxes significantly $(p>0.05)$. Cumulatively, mean annual $\mathrm{N}_{2} \mathrm{O}$ fluxes from the natural and rice paddy wetlands ranged from $4.4-6.1 \mathrm{mg} \mathrm{m}^{-2} \mathrm{yr}^{-1}$, with annual carbon dioxide equivalents $\left(\mathrm{CO}_{2} \mathrm{e}\right)$ ranging from $1.2-1.6$ $\mathrm{g} \mathrm{m}^{-2} \mathrm{yr}^{-1}$ (Table 2).

Whereas mean $\mathrm{N}_{2} \mathrm{O}$ fluxes did not vary significantly between both wetlands and seasons, individual fluxes showed great variations even within the same wetland/vegetation community and season. However, the variations were much more pronounced in the rice paddy wetland, as can be shown by the extent of whiskers in Figs. 3 and 4. For instances, during the dry season, individual $\mathrm{N}_{2} \mathrm{O}$ fluxes varied from - 5.2-5.5, $-4.9-6.3$ and $-4.4-5.8 \mu \mathrm{g} \mathrm{m}^{-2} \mathrm{~h}^{-1}$ with respect to the Typha, Phragmites and Papyrus vegetation communities of the natural wetland, compared to $-10.1-14 \mu \mathrm{g} \mathrm{m}^{-2} \mathrm{~h}^{-1}$ from the rice paddy wetland. During the wet season, individual $\mathrm{N}_{2} \mathrm{O}$ fluxes ranged from $-4.4-5.2,-4.5-4.7,-4.7-4.9 \mu \mathrm{g} \mathrm{m}^{-2}$ $\mathrm{h}^{-1}$ from Typha, Phragmites and Papyrus respectively, compared to $-7.5-11.8 \mu \mathrm{g} \mathrm{m}^{-2} \mathrm{~h}^{-1}$ from the rice paddy wetland. This can explain the big divergence of the mean and median $\mathrm{N}_{2} \mathrm{O}$ flux values in both wetlands during the two sampling seasons (Figs. 3 and 4). 
Table 2

Nitrous oxide $\left(\mathrm{N}_{2} \mathrm{O}\right)$ fluxes from the natural and rice paddy wetlands and their carbon dioxide equivalents $\left(\mathrm{CO}_{2} \mathrm{e} ; \mathrm{n}=72\right)$

\begin{tabular}{|c|c|c|c|c|c|c|}
\hline \multirow{2}{*}{$\begin{array}{l}\text { Wetland } \\
\text { Natural }\end{array}$} & \multicolumn{3}{|c|}{$\mathrm{N} 20\left(\mu \mathrm{g} \mathrm{m}^{-2} \mathrm{~h}^{-1}\right)$} & \multirow{2}{*}{$\begin{array}{l}\mathrm{N}_{2} \mathrm{O}\left(\mu \mathrm{g} \mathrm{m}^{-2}\right. \\
\left.\mathrm{d}^{-1}\right)\end{array}$} & \multirow{2}{*}{$\begin{array}{l}\mathrm{N}_{2} \mathrm{O}\left(\mathrm{mg} \mathrm{m}^{-2}\right. \\
\left.\mathrm{yr}^{-1}\right)\end{array}$} & \multirow{2}{*}{$\begin{array}{l}\mathrm{CO}_{2} \mathrm{e}^{\star}\left(\mathrm{g} \mathrm{m}^{-2}\right. \\
\left.\mathrm{yr}^{-1}\right)\end{array}$} \\
\hline & $\begin{array}{l}\text { Wet } \\
\text { season }\end{array}$ & $\begin{array}{l}\text { Dry } \\
\text { season }\end{array}$ & Average & & & \\
\hline Typha & $0.5 \pm 1.4$ & $0.6 \pm 1.6$ & $\begin{array}{l}0.6 \pm \\
1.5\end{array}$ & $14.4 \pm 36.0$ & $5.3 \pm 13.1$ & $1.4 \pm 3.5$ \\
\hline Phragmites & $0.4 \pm 1.5$ & $0.5 \pm 1.7$ & $\begin{array}{l}0.5 \pm \\
1.6\end{array}$ & $12.0 \pm 38.4$ & $4.4 \pm 14.0$ & $1.2 \pm 3.7$ \\
\hline Papyrus & $0.5 \pm 1.5$ & $0.5 \pm 1.3$ & $\begin{array}{l}0.5 \pm \\
1.4\end{array}$ & $12.0 \pm 33.6$ & $4.4 \pm 12.3$ & $1.2 \pm 3.2$ \\
\hline Average & $0.5 \pm 1.5$ & $0.5 \pm 1.5$ & $\begin{array}{l}0.5 \pm \\
1.5\end{array}$ & $12.0 \pm 36.0$ & $4.4 \pm 13.1$ & $1.2 \pm 3.5$ \\
\hline Rice paddy & $0.6 \pm 2.7$ & $0.7 \pm 2.8$ & $\begin{array}{l}0.7 \pm \\
2.8\end{array}$ & $16.8 \pm 48.8$ & $6.1 \pm 17.8$ & $1.6 \pm 4.7$ \\
\hline
\end{tabular}

\subsection{Effect of Soil Physico-chemical and Water Level Characteristics on Nitrous Oxide Emission}

The relationship between soil physico-chemical and surface water level characteristics and $\mathrm{N}_{2} \mathrm{O}$ fluxes from the wetlands is depicted in Table 3. As shown by the Spearman's rank order correlation coefficients, soil physical chemical parameters temperature, $\mathrm{pH}$ and TN positively correlated with $\mathrm{N}_{2} \mathrm{O}$ flux, unlike OC, salinity and C: $\mathrm{N}$ that showed negative correlations. Similarly, the correlation between surface water level and $\mathrm{N}_{2} \mathrm{O}$ flux was negative. In terms of the magnitude of the correlations, neither soil physico-chemical characteristics nor surface water level significantly correlated $(p>0.05)$ with $\mathrm{N}_{2} \mathrm{O}$. 
Table 3

Correlation between $\mathrm{N}_{2} \mathrm{O}$ flux and soil temperature, $\mathrm{pH}$, nitrogen, organic carbon, salinity, carbon to nitrogen ration, and surface water level $(n=36)$

\begin{tabular}{|c|c|c|c|c|c|c|c|c|}
\hline & N2O & Temp & $\mathrm{pH}$ & $\mathbf{N}$ & OC & Salinity & C:N & S. water leve \\
\hline $\mathrm{N} 2 \mathrm{O}$ & 1.00 & & & & & & & \\
\hline Temp & 0.26 & 1.00 & & & & & & \\
\hline $\mathrm{pH}$ & 0.03 & 0.19 & 1.00 & & & & & \\
\hline TN & 0.28 & -0.21 & -0.29 & 1.00 & & & & \\
\hline $\mathrm{OC}$ & -0.05 & $-0.34^{*}$ & -0.10 & $-0.46 *$ & 1.00 & & & \\
\hline Sal & -0.06 & 0.07 & -0.03 & 0.24 & -0.16 & 1.00 & & \\
\hline $\mathrm{C}: \mathrm{N}$ & -0.21 & 0.17 & -0.23 & -0.21 & 0.25 & 0.09 & 1.00 & \\
\hline S. water level & -0.26 & -0.55 & -0.40 & 0.42 & 0.37 & 0.35 & 0.32 & 1.00 \\
\hline
\end{tabular}

\section{Discussion}

\subsection{Nitrous Oxide Emission from the Natural and Rice Paddy Wetlands}

Within the natural wetland, $\mathrm{N}_{2} \mathrm{O}$ fluxes did vary significantly across vegetation communities. Similar results have been reported from other studies elsewhere, such as North Dakota, USA (Phillips and Beeri, 2008), Denmark (Audet et al. 2014) and Mexico (Hernández and Junca-Gómez 2020). Some studies have shown that vegetation community affects $\mathrm{N}_{2} \mathrm{O}$ fluxes from wetlands. Liu et al. (2014) showed that emissions of $\mathrm{N}_{2} \mathrm{O}$ from two vegetated coastal wetland zones, one dominated by Spatina spp. and the other dominated by Phragmites spp. differed significantly, with the Phragmites spp. zone showing higher $\mathrm{N}_{2} \mathrm{O}$ flux, even though both zones were at the same altitude. This observation was explained by differences in biomass productivity, which affects the resultant organic matter and nitrogen input into soil. This is further supported by Piñeiro-Guerra et al. (2019), whose study across several sites in Argentina showed that $\mathrm{N}_{2} \mathrm{O}$ emission increased with primary productivity. Wang et al. (2008) investigated the impact of plant species on $\mathrm{N}_{2} \mathrm{O}$ emission, using constructed wetlands. Results indicated that the wetland planted with Zizania latifolia had a higher emission of $\mathrm{N}_{2} \mathrm{O}$ compared to those planted with Phragmites australis and Typha latifolia. They attributed the results to differences in root structure of the plant species, where the root structure of Zizania latifolia was favored by ammonia oxidizing bacteria for $\mathrm{N}_{2} \mathrm{O}$ formation. Abalos et al. (2018) investigated plant functional traits that may affect $\mathrm{N}_{2} \mathrm{O}$ emission and 
noted that specific leaf area and root length density were key traits that did not only regulate $\mathrm{N}_{2} \mathrm{O}$ emission but also biomass productivity.

Wetland conversion/land use change, from natural to rice paddy wetland has been shown to enhance $\mathrm{N}_{2} \mathrm{O}$ emissions from wetlands (Liengaard et al. 2013; Owino et al. 2020). This is attached two reasons: i) water table drawdown through drainage favors oxygen availability, thus increasing the mineralization of soil organic nitrogen and nitrification processes (Ajwang'Ondiek et al. 2021; Liengaard et al. 2013), and ii) nitrogen fertilization of rice paddy fields to enhance rice yields increases nitrogen availability in soil, a substrate for nitrification/denitrification processes (Owino et al. 2020). Liengaard et al. (2013) reported that partial soil wetting by light rain in a tropical South American freshwater wetland resulted into high $\mathrm{N}_{2} \mathrm{O}$ emission compared to long-term soil waterlogging following heavy rain. In China, Yang et al. (2013) observed that $\mathrm{N}_{2} \mathrm{O}$ emission from a natural marsh wetland increased by $120 \%$ as the water level reduced from $+14 \mathrm{~cm}$ to $-11 \mathrm{~cm}$. Liu et al. (2020) have estimated that agricultural drainage of European (EU-28) peatlands has caused annual $\mathrm{N}_{2} \mathrm{O}$ emissions from these managed peatlands of $145 \mathrm{Gg} \mathrm{N} \mathrm{yr}^{-1}$. They further indicated that rewetting of all drained European peatlands could cut the cumulative $\mathrm{N}_{2} \mathrm{O}$ emissions by $70 \%$. Similarly, a recent synthesis of several studies on the effect of wetting and drying cycles on $\mathrm{N}_{2} \mathrm{O}$ emission from freshwater sediments has reported $\mathrm{N}_{2} \mathrm{O}$ pulses following sediment drying and rewetting events, with exposed sediments being active spots for $\mathrm{N}_{2} \mathrm{O}$ emissions during dry phases (Pinto et al. 2021).

Owino et al. (2020) reported that conversation of Papyrus wetlands into nitrogen fertilized rice paddies in Kenya significantly increased $\mathrm{N}_{2} \mathrm{O}$ emission $\left(4.37 \pm 3.18 \mathrm{\mu g} \mathrm{m}^{-2} \mathrm{~h}^{-1}\right.$ from the fertilized fields against $3.59 \pm 2.5618 \mu \mathrm{g} \mathrm{m}^{-2} \mathrm{~h}^{-1}$ from the unfertilized fields). Zhang et al. (2014) also reported a positive correlation between the amount of nitrogen fertilizer application and $\mathrm{N}_{2} \mathrm{O}$ emissions from rice paddies, irrespective of the rice growth stage. Therefore, the lack of significant difference in $\mathrm{N}_{2} \mathrm{O}$ fluxes from the natural and rice paddy wetlands in this study could be explained as follows: i) both the natural and rice paddy wetlands were continuously flooded throughout the sampling period, so water table could not significantly affect $\mathrm{N}_{2} \mathrm{O}$ fluxes from both wetlands, as was indeed shown by lack of a significant correlation between water level and $\mathrm{N}_{2} \mathrm{O}$ flux (Table 3), and ii) fertilization of the rice paddy fields studied is not done, as rice cultivation is only reliant on the natural fertility of the soil. Undoubtedly, soil nitrogen contents of natural and rice paddy wetlands were not different, as was seen in Table 1.

Seasonal variations did not affect $\mathrm{N}_{2} \mathrm{O}$ fluxes from both wetlands. Seasonal variation in $\mathrm{N}_{2} \mathrm{O}$ emissions, especially associated with temperature differences (summer vs winter seasons) have been reported in temperate wetlands (Czóbel et al. 2020; Jørgensen and Elberling 2012). Warmer soil temperatures during summer seasons have been shown to enhance microbial activities, resulting into increased mineralization of organic nitrogen in soils. However, in tropical regions, it is shown that temperature is unlikely to exert a minimal control on GHGs fluxes from wetlands because temperatures are relatively stable, irrespective of season (Sjögersten et al. 2014). However, in many tropical wetlands, seasonal 
changes are usually associated with changes in water table e.g. drying and flooding cycles during the dry and wet seasons, respectively (Bernal and Mitsch 2013). Therefore, in such cases (drying and wetting cycles), seasonal $\mathrm{N}_{2} \mathrm{O}$ flux from those wetlands is likely to be driven more by changes in the water table depth rather than soil temperature. However, it has also been indicated that seasonal $\mathrm{N}_{2} \mathrm{O}$ fluxes based on wetting and drying cycles are more pronounced in wetland systems influenced by anthropogenic input on nitrogen (Hernandez and Mitsch et al. 2006). In the present study, seasonal changes (dry vs wet) were not associated with drying and wetting cycles as water level was above the soil surface in both seasons, and neither were the wetlands affected by anthropogenic nitrogen input. Thus, this could explain why $\mathrm{N}_{2} \mathrm{O}$ emission did not vary between the dry and wet seasons.

This study showed great variations in individual $\mathrm{N}_{2} \mathrm{O}$ fluxes even within the same wetland/vegetation community/season, with values ranging from negative (indicating $\mathrm{N}_{2} \mathrm{O}$ consumption) to positive (indicating $\mathrm{N}_{2} \mathrm{O}$ emission) (Figs. 3 and 4). This has also been reported by other studies (Ajwang'Ondiek et al. 2021; Audet et al. 2014; Owino et al. 2020), where it is attributed to wetland soils acting as both $\mathrm{N}_{2} \mathrm{O}$ sinks and sources. Schlesinger (2013) and Wu et al (2013) have explained that soils act as sinks of $\mathrm{N}_{2} \mathrm{O}$ when $\mathrm{N}_{2} \mathrm{O}$ is consumed during either nitrification or denitrification, largely under conditions of limited nitrate $\left(\mathrm{NO}_{3}{ }^{-}\right)$.

In this study, we observed no significant correlation between soil physico-chemical characteristic and $\mathrm{N}_{2} \mathrm{O}$ from the wetlands. Audet et al. (2014) explored the factors controlling $\mathrm{N}_{2} \mathrm{O}$ uptake and emission from several natural wetlands. They also established that no significant correlation between $\mathrm{N}_{2} \mathrm{O}$ emission and soil physico-chemical characteristics. Instead, they observed that ammonium concentration in the groundwater was the only parameter that exerted a significant control on $\mathrm{N}_{2} \mathrm{O}$ fluxes from the wetlands. Richards and Craft (2015) have explained that emission of GHGs, including $\mathrm{N}_{2} \mathrm{O}$ from wetlands is an interplay between several factors, with the key controlling factor(s) varying depending on the existing conditions.

In Uganda, no study has evaluated the totality of $\mathrm{N}_{2} \mathrm{O}$ emissions from the country's natural and rice paddy wetlands. Therefore, to provide a basis for future studies, we used our study findings to roughly estimate total annual $\mathrm{N}_{2} \mathrm{O}$ emissions from Uganda's natural and rice paddy wetlands. To achieve this, we made a simple assumption that other natural and rice paddy wetlands in the country present more or less similar conditions to our study wetlands. Natural wetlands in the Uganda cover about $26,165 \mathrm{~km}^{2}$ compared to $150 \mathrm{~km}^{2}$ occupied by rice paddy wetlands (Were et al. 2021b). We obtained mean annual $\mathrm{N}_{2} \mathrm{O}$ emission from the natural and rice paddy as $4.4 \pm 13.1 \mathrm{mg} \mathrm{m}^{-2} \mathrm{yr}^{-1}$ and $6.1 \pm 17.8 \mathrm{mg} \mathrm{m}^{-2} \mathrm{yr}^{-1}$ (Table 2). Therefore, total $\mathrm{N}_{2} \mathrm{O}$ emissions from Uganda's natural and rice paddy wetlands are estimated at $115.1 \pm 342.8 \mathrm{~T} \mathrm{yr}^{-1}\left(\mathrm{CO}_{2} \mathrm{e}=30,501.5 \pm 90,842 \mathrm{~T} \mathrm{yr}^{-1}\right)$ and $0.9 \pm 2.7 \mathrm{~T} \mathrm{yr}^{-1}\left(\mathrm{CO}_{2} \mathrm{e}=242.5 \pm 707.6 \mathrm{~T} \mathrm{yr}^{-1}\right)$, respectively. 


\subsection{Implication of Permanently Flooded Rice Cultivation under no Fertilization on Climate Change Mitigation}

To mitigate climate change and its impacts, the IPCC (2014) has emphasized increasing carbon sequestration while at the same time minimizing emission of GHGs into the atmosphere. Some of the suggested measures to increase carbon sequestration include protection and conservation of natural ecosystems such as forests, grasslands, and wetlands. Wetlands are unique ecosystems, where water is the terminal parameter that influence the development of soil and plant characteristics different from other ecosystems. These unique characteristics have a great influence on carbon and nitrogen cycling in these ecosystems (Mitsch et al. 2013). Several studies have acknowledged that conversion of natural wetlands in farmed wetlands compromises climate change mitigation by enhancing carbon and nitrogen emission (Ajwang'Ondiek et al. 2021; Owino et al. 2020; Were et al. 2020b). As earlier explained, water drawdown in rice paddy has been attributed to enhanced carbon emissions from these ecosystems (Were et al. 2019; Were et al. 2021b), while water table drawdown alongside nitrogen fertilizer application are responsible for high nitrogen fluxes from these ecosystems (Owino et al. 2020). With the increasing human population globally, increased food demand implies natural tropical freshwater wetlands will remain under high pressure of conversion into rice paddies. Indeed, Davidson and Finlayson (2018) have reported an average increase in rice paddy acreage of $0.62 \%$ per year. As result, climate change mitigation efforts need to explore ways of optimizing carbon sequestration while minimizing emission of GHGs such as $\mathrm{N}_{2} \mathrm{O}$ from rice paddy wetlands. Basing on the results of this study, therefore, rice cultivation under continuous flooding and no nitrogen fertilizer application enhances climate change mitigation as it minimizes $\mathrm{N}_{2} \mathrm{O}$ fluxes into the atmosphere. However, continuously flooded conditions in wetlands are also known to enhance $\mathrm{CH}_{4}$ emission to the atmosphere (Were et al. 2019). Nevertheless, it has already been shown that undrained wetlands represent net carbon sinks of about $830 \mathrm{~T} \mathrm{C} \mathrm{yr}^{-1}$ (Mitsch et al. 2013), indicating that the emitted $\mathrm{CH}_{4}$ is compensated by the $\mathrm{CO}_{2}$ sequestered.

\section{Conclusions}

Emission of $\mathrm{N}_{2} \mathrm{O}$ from the natural tropical freshwater wetland was not affected by vegetation community, as emission rates from the Typha, Phragmites and Papyrus vegetation communities did not differ significantly. Further, $\mathrm{N}_{2} \mathrm{O}$ emission did not vary between the natural and rice paddy wetlands. Therefore, under conditions of continuous flooding, vegetation community has no effect on $\mathrm{N}_{2} \mathrm{O}$ emission from a natural tropical freshwater wetland. Likewise, under continuous flooding and no fertilizer (nitrogen) application, conversion of a natural tropical wetland into a rice paddy wetland does not affect $\mathrm{N}_{2} \mathrm{O}$ emission. Additionally, seasonal variations (dry vs wet) has no effect on $\mathrm{N}_{2} \mathrm{O}$ emission from a natural tropical freshwater wetland and rice paddy under conditions of continuous flooding and no nitrogen fertilizer application. Soil physico-chemical characteristics showed no significant correlation with $\mathrm{N}_{2} \mathrm{O}$ flux from the wetlands, implying that $\mathrm{N}_{2} \mathrm{O}$ emission was an interplay between several factors, with no single dominant factor. 


\section{Declarations}

\section{Authors' Contributions}

The study was conceptualized and designed by DW. DW carried out data collection and analysis, and wrote, edited and reviewed the first draft manuscript. TH edited, reviewed and contributed to the discussion of the manuscript. Funding acquisition was by $\mathrm{TH}$. The study was supervised by $\mathrm{TH}$. All authors read and approved the final manuscript.

\section{Funding}

This work was supported by University of Natural Resources and Life Sciences (BOKU), Vienna, Austria, through Mag. Gerold Winkler and Prof. Thomas Hein (Granted under student number GSR/9813/10).

\section{Conflict of interest}

On behalf of all authors, the corresponding author states that there is no conflict of interest.

\section{Ethics approval}

Ethics approval was not required for this study

\section{Consent to participate}

Not Applicable

\section{Consent for publication}

Not Applicable

\section{Availability of data and material}

Not Applicable

\section{Code availability}

Not Applicable

\section{References}

1. Abalos D, van Groenigen JW, De Deyn GB (2018) What plant functional traits can reduce nitrous oxide emissions from intensively managed grasslands? Glob Change Biol 24:e248-e258. https://doi.org/10.1111/gcb.13827

2. Ajwang'Ondiek R, Hayes DS, Kinyua DN, Kitaka N, Lautsch E, Mutuo P, Hein T (2021) Influence of land-use change and season on soil greenhouse gas emissions from a tropical wetland: a stepwise 
explorative assessment. Sci Total Environ 787. https://doi.org/10.1016/j.scitotenv.2021.147701

3. Audet J, Hoffmann CC, Andersen PM, Baattrup-Pedersen A, Johansen JR, Larsen SE, Kjaergaard C, Elsgaard L (2014) Nitrous oxide fluxes in undisturbed riparian wetlands located in agricultural catchments: Emission, uptake and controlling factors. Soil Biol Biochem 1:68:291-299. https://doi.org/10.1016/j.soilbio.2013.10.011

4. Bernal B, Mitsch WJ (2013) Carbon sequestration in freshwater wetlands in Costa Rica and Botswana. Biogeochem 115:77-93. https://doi.org/10.1007/s10533-012-9819-8

5. Boateng K, Obeng G, Mensah E (2017) Rice cultivation and greenhouse gas emissions: a review and conceptual framework with reference to Ghana. Agric 7. https://doi.org/10.3390/agriculture7010007

6. Butterbach-Bahl K, Kiese R, Liu C (2011) Measurements of biosphere-atmosphere exchange of $\mathrm{CH} 4$ in terrestrial ecosystems. Methods Enzymol 495:271 - 87. https://doi.org/10.1016/B978-0-12386905-0.00018-8

7. Butterbach-Bahl K, Sander BO, Pelster D, Díaz-Pinés E (2016) Quantifying greenhouse gas emissions from managed and natural soils. In: Methods for Measuring Greenhouse Gas Balances and Evaluating Mitigation Options in Smallholder Agriculture. Springer, Cham, pp 71-96

8. Czóbel S, Horváth L, Szirmai O, Balogh J, Pintér K, Németh Z, Ürmös Z, Grosz B, Tuba Z (2010) Comparison of $\mathrm{N}_{2} \mathrm{O}$ and $\mathrm{CH}_{4}$ fluxes from Pannonian natural ecosystems. Eur J Soil Sci 61(5):671682. https://doi.org/10.1111/j.1365-2389.2010.01275.x

9. Davidson NC, Finlayson CM (2018) Extent, regional distribution and changes in area of different classes of wetland. Mar Freshw Res 69:1525-1533. https://doi.org/10.1071/MF17377

10. Hedin LO, Brookshire EJ, Menge DN, Barron AR (2009) The nitrogen paradox in tropical forest ecosystems. Annual Rev Ecol Evol Syst 40:613-635.

https://doi.org/10.1146/annurev.ecolsys.37.091305.110246

11. Hernández ME, Junca-Gómez D (2020) Carbon stocks and greenhouse gas emissions $\left(\mathrm{CH}_{4}\right.$ and $\left.\mathrm{N}_{2} \mathrm{O}\right)$ in mangroves with different vegetation assemblies in the central coastal plain of Veracruz Mexico. Sci Total Environ 741. https://doi.org/10.1016/j.scitotenv.2020.140276

12. Hernandez ME, Mitsch WJ (2006) Influence of hydrologic pulses, flooding frequency, and vegetation on nitrous oxide emissions from created riparian marshes. Wetl 26:862 - 77. https://doi.org/10.1672/0277-5212(2006)26[862:IOHPFF]2.0.C0;2

13. Inglett KS, Inglett PW, Reddy KR, Osborne TZ (2012) Temperature sensitivity of greenhouse gas production in wetland soils of different vegetation. Biogeochem 108:77-90. https://doi.org/10.1007/s10533-011-9573-3

14. IPCC (2007) Climate Change 2007: The Physical Science Basis. Contribution of Working Group I to the Fourth Assessment Report of the Intergovernmental Panel on Climate Change. Cambridge, NY: Cambridge University Press. https://www.ipcc.ch/site/assets/uploads/2018/05/ar4_wg1_full_report1.pdf (Accessed 25 June 2021)

15. IPCC (2013) Climate Change 2013: The Physical Science Basis. Contribution of Working Group I to the Fifth Assessment Report of the Intergovernmental Panel on Climate Change [Stocker, T.F., D. Qin, 
G.-K. Plattner, M. Tignor, S.K. Allen, J. Boschung, A. Nauels, Y. Xia, V. Bex and P.M. Midgley (eds.)]. Cambridge University Press, Cambridge, United Kingdom and New York, NY, USA, pp. 1535. https://www.ipcc.ch/site/assets/uploads/2018/02/WG1AR5_all_final.pdf (Accessed 19 May 2021)

16. IPCC (2014) Climate Change 2014: Synthesis Report. Contribution of Working Groups I, II and III to the Fifth Assessment Report of the Intergovernmental Panel on Climate Change [Core Writing Team, R.K. Pachauri and L.A. Meyer (eds.)]. IPCC, Geneva, Switzerland, pp 151. https://www.ipcc.ch/site/assets/uploads/2018/02/SYR_AR5_FINAL_full.pdf (Accessed 10 July 2021)

17. Jones MB, Kansiime F, Saunders MJ (2018) The potential use of Papyrus (Cyperus papyrus L.) wetlands as a source of biomass energy for sub-Saharan Africa. GCB Bioenergy 10:4-11. https://doi.org/10.1111/gcbb.12392

18. Jørgensen CJ, Elberling B (2012) Effects of flooding-induced N2O production, consumption and emission dynamics on the annual N2O emission budget in wetland soil. Soil Biol Biochem 53:9-17. https://doi.org/10.1016/j.soilbio.2012.05.005

19. Kayendeke EJ, Kansiime F, French HK, Bamutaze Y (2018) Spatial and temporal variation of Papyrus root mat thickness and water storage in a tropical wetland system. Sci Total Environ 642:925-936. https://doi.org/10.1016/j.scitotenv.2018.06.087

20. Liengaard L, Nielsen LP, Revsbech NP, Priemé A, Elberling B, Enrich-Prast A, Kühl M (2013) Extreme emission of $\mathrm{N}_{2} \mathrm{O}$ from tropical wetland soil (Pantanal, South America). Front Microbiol 3:433. https://doi.org/10.3389/fmicb.2012.00433

21. Liu H, Wrage-Mönnig N, Lennartz B (2020) Rewetting strategies to reduce nitrous oxide emissions from European peatlands. Commun Earth Environ 1:1-7. https://doi.org/10.1038/s43247-02000017-2

22. Liu Y, Wang L, Bao S, Liu H, Yu J, Wang Y, Shao H, Ouyang Y (2014) An S. Effects of Different Vegetation Zones on $\mathrm{CH} 4$ and N2O Emissions in Coastal Wetlands: A Model Case Study. Sci World J. https://doi.org/10.1155/2014/412183

23. Millennium Ecosystem Assessment (2005) Ecosystems and Human Well-being: Synthesis. Island Press, Washington, DC. http://pdf.wri.org/mea_synthesis_030105.pdf

24. Minamikawa K, Tokida T, Sudo S, Padre A, Yagi K (2015) Guidelines for measuring $\mathrm{CH}_{4}$ and $\mathrm{N}_{2} \mathrm{O}$ emissions from rice paddies by a manually operated closed chamber method. National Institute for Agro-Environmental Sciences, Tsukuba, Japan.

http://www.naro.affrc.go.jp/archive/niaes/techdoc/mirsa_guidelines.pdf (Accessed 20 June 2021)

25. Mitsch WJ, Bernal B, Nahlik AM, Mander Ü, Zhang L, Anderson CJ, Jørgensen SE, Brix H (2013) Wetlands, carbon, and climate change. Landsc Ecol 28:583-597. https://doi.org/10.1007/s10980012-9758-8

26. Owino CN, Kitaka N, Kipkemboi J, Ajwang'Ondiek R (2020) Assessment of Greenhouse Gases Emission in Smallholder Rice Paddies Converted from Anyiko Wetland, Kenya. Front Environ Sci 8:80. https://doi.org/10.3389/fenvs.2020.00080 
27. Pärn J, Verhoeven JT, Butterbach-Bahl K, Dise NB, Ullah S, Aasa A, Egorov S, Espenberg M, Järveoja J, Jauhiainen J, Kasak K (2018) Nitrogen-rich organic soils under warm well-drained conditions are global nitrous oxide emission hotspots. Nat Commun 9:1-8. https://doi.org/10.1038/s41467-01803540-1

28. Phillips R, Beeri $O$ (2008) The role of hydropedologic vegetation zones in greenhouse gas emissions for agricultural wetland landscapes. Catena 72:386-394.

https://doi.org/10.1016/j.catena.2007.07.007

29. Piñeiro-Guerra JM, Yahdjian L, Della Chiesa T, Piñeiro G (2019) Nitrous oxide emissions decrease with plant diversity but increase with grassland primary productivity. Oecologia 190:497-507. https://doi.org/10.1007/s00442-019-04424-x

30. Pinto R, Weigelhofer G, Brito AG, Hein T (2021) Effects of dry-wet cycles on nitrous oxide emissions in freshwater sediments: a synthesis. PeerJ 9:e10767. https://doi.org/10.7717/peerj.10767

31. Richards B, Craft CB (2015) Greenhouse gas fluxes from restored agricultural wetlands and natural wetlands, Northwestern Indiana. In: Vymazal J (ed) The Role of Natural and Constructed Wetlands in Nutrient Cycling and Retention on the Landscape. Springer, Cham, pp 17-32. https://doi.org/10.1007/978-3-319-08177-9_2

32. Rochette P, Bertrand N, Carter M, Gregorich EG (2008) Soil-surface gas emissions. Soil sampling and methods of analysis. CRC Press, Boca Raton, pp 851-861

33. Schlesinger WH (2013) An estimate of the global sink for nitrous oxide in soils. Glob Change Biol 19(10):2929-2931. https://doi.org/10.1111/gcb.12239

34. Sjögersten S, Black CR, Evers S, Hoyos-Santillan J, Wright EL, Turner BL (2014) Tropical wetlands: A missing link in the global carbon cycle? Glob Biogeochem Cycles 28:1371-1386. https://doi.org/10.1002/2014GB004844

35. Tian H, Chen G, Lu C, Xu X, Ren W, Zhang B, Banger K, Tao B, Pan S, Liu M, Zhang C (2015) Global methane and nitrous oxide emissions from terrestrial ecosystems due to multiple environmental changes. Ecosyst Health Sustain 1:1-20. https://doi.org/10.1890/EHS14-0015.1

36. Wang Y, Inamori R, Kong H, Xu K, Inamori Y, Kondo T, Zhang J (2008) Nitrous oxide emission from polyculture constructed wetlands: effect of plant species. Environ Pollut 152:351-360. https://doi.org/10.1016/j.envpol.2007.06.017

37. Were D, Kansiime F, Fetahi T, Cooper A, Jjuuko C (2019) Carbon sequestration by wetlands: a critical review of enhancement measures for climate change mitigation. Earth Syst Environ 3:327-340. https://doi.org/10.1007/s41748-019-00094-0

38. Were D, Kansiime F, Fetahi T, Hein T (2020a) Soil organic carbon storage in a tropical freshwater wetland: the influence of vegetation type. Afr J Aquat Sci 46:161-172. https://doi.org/10.2989/16085914.2020.1804821

39. Were D, Kansiime F, Fetahi T, Hein T (2020b) A natural tropical freshwater wetland is a better climate change mitigation option through soil organic carbon storage compared to a rice paddy wetland. SN Appl Sci. https://doi.org/10.1007/s42452-020-2746-8 
40. Were D, Kansiime F, Fetahi T, Hein T (2021a) Carbon dioxide and methane fluxes from various vegetation communities of a natural tropical freshwater wetland in different seasons. Environ Processes 8:553-571. https://doi.org/10.1007/s40710-021-00497-0

41. Were D, Kansiime F, Fetahi T, Hein T (2021b) Carbon Dioxide and Methane Fluxes from a Tropical Freshwater Wetland Under Natural and Rice Paddy Conditions: Implications for Climate Change Mitigation. Wetl 52. https://doi.org/10.1007/s13157-021-01451-4

42. WMO (2019) WMO Greenhouse Gas Bulletin: The State of Greenhouse Gases in the Atmosphere Based on Global Observations through 2018. https://library.wmo.int/index.php? Ivl=notice_display\&id=21620\#.Xwh21igzbIV (Accessed 5 May 2021)

43. Wu J, Zhang J, Jia W, Xie H, Gu RR, Li C, Gao B (2009) Impact of COD/N ratio on nitrous oxide emission from microcosm wetlands and their performance in removing nitrogen from wastewater. Bioresource Technol 100:2910-2917. https://doi.org/10.1016/j.biortech.2009.01.056

44. Yang H, Chen X, Tang J, Zhang L, Zhang C, Perry DC, You W (2019) External carbon addition increases nitrate removal and decreases nitrous oxide emission in a restored wetland. Ecol Eng 138:200-208. https://doi.org/10.1016/j.ecoleng.2019.07.021

45. Yang J, Liu J, Hu X, Li X, Wang Y, Li H (2013) Effect of water table level on $\mathrm{CO}_{2}, \mathrm{CH}_{4}$ and $\mathrm{N}_{2} \mathrm{O}$ emissions in a freshwater marsh of Northeast China. Soil Biol Biochem 61:52-60. https://doi.org/10.1016/j.soilbio.2013.02.009

46. Zhang X, Yin S, Li Y, Zhuang H, Li C, Liu C (2014) Comparison of greenhouse gas emissions from rice paddy fields under different nitrogen fertilization loads in Chongming Island, Eastern China. Sci Total Environ 472:381-388. https://doi.org/10.1016/j.scitotenv.2013.11.014

\section{Figures}




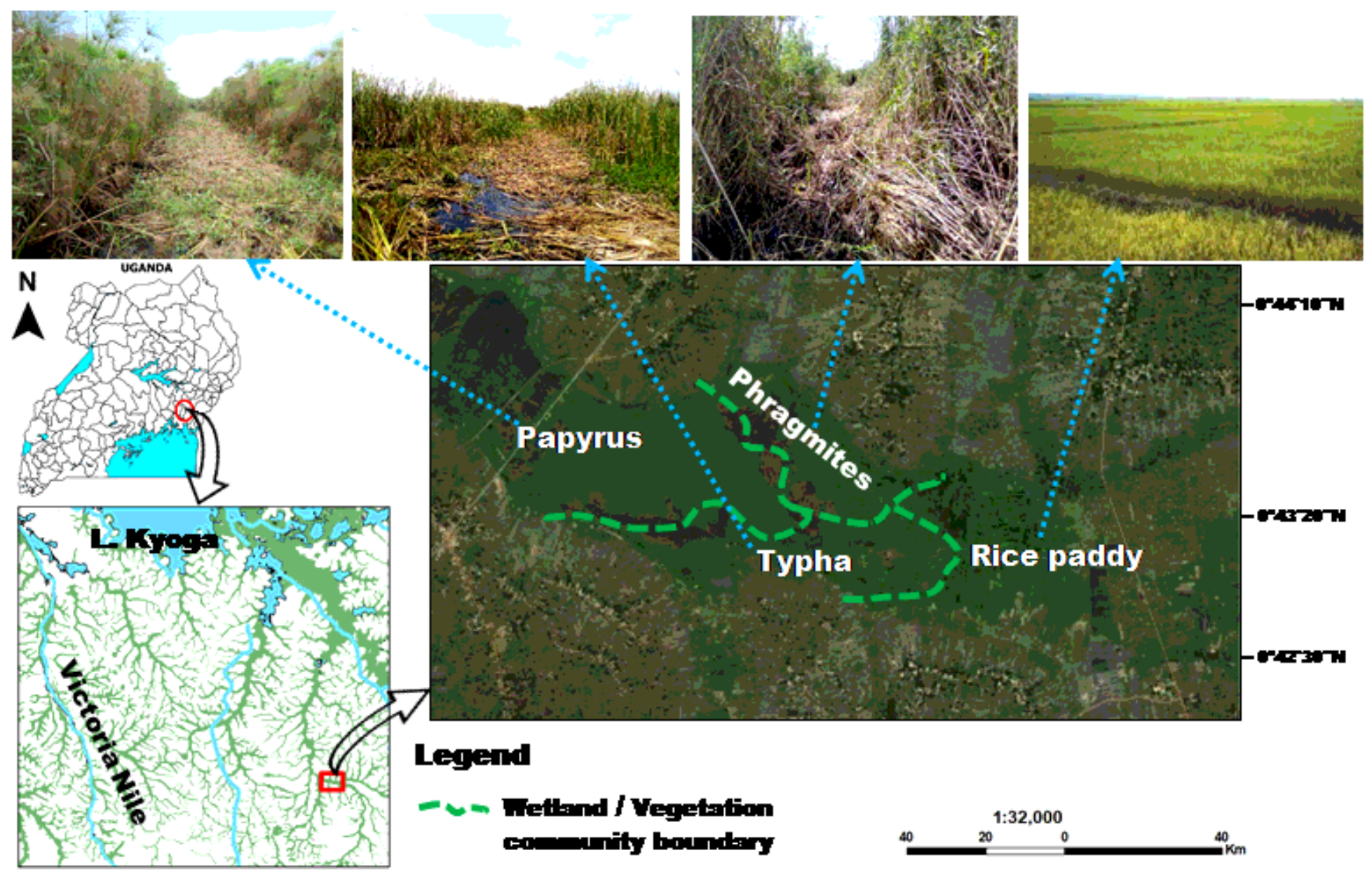

Figure 1

Location of study wetland. The study area was zoomed and geo-referenced from Google Earth

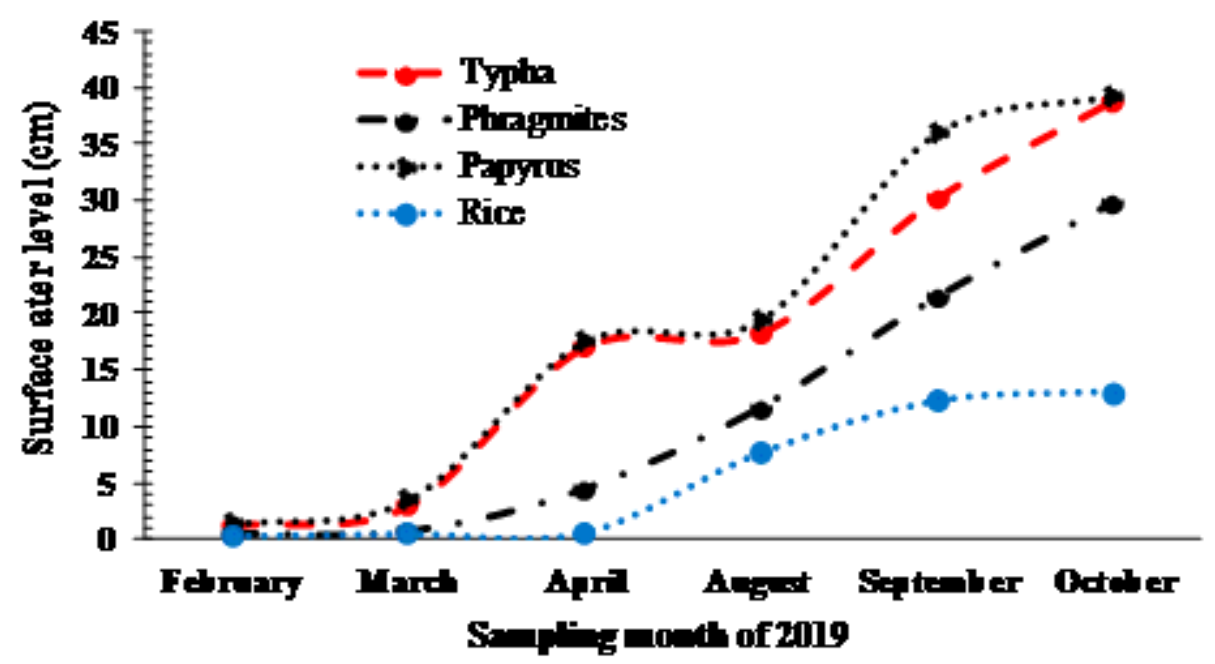

Figure 2 
Variation of surface water level the natural (Typha, Phragmites and Papyrus) and rice paddy (Rice) wetlands during the dry (February, March and April) and wet (August, September and October) seasons

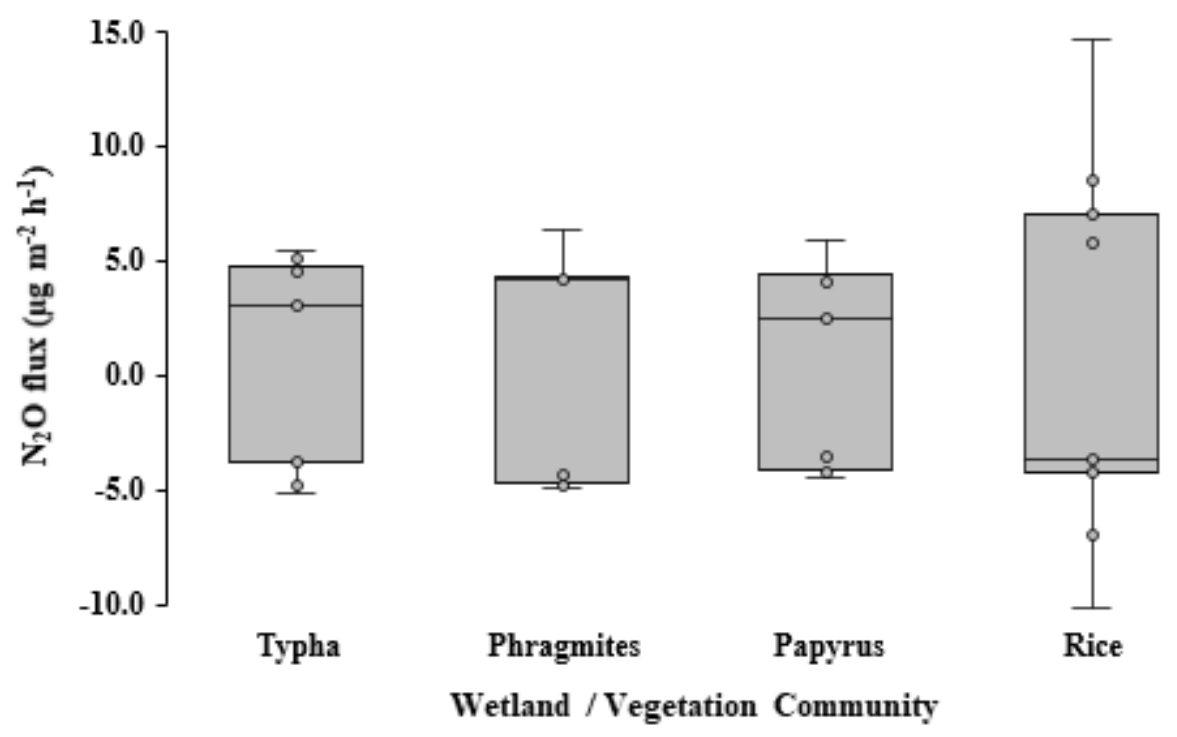

\section{Figure 3}

Comparison of N2O fluxes from the natural (Papyrus, Typha and Phragmites) and rice paddy (Rice) wetlands during the dry season. Box lines show upper and lower quartiles, while horizontal lines within boxes show median values $(n=72)$. Whiskers extend to the minimum and maximum values. Mean values are not significant across wetlands/vegetation communities $(p>0.05)$

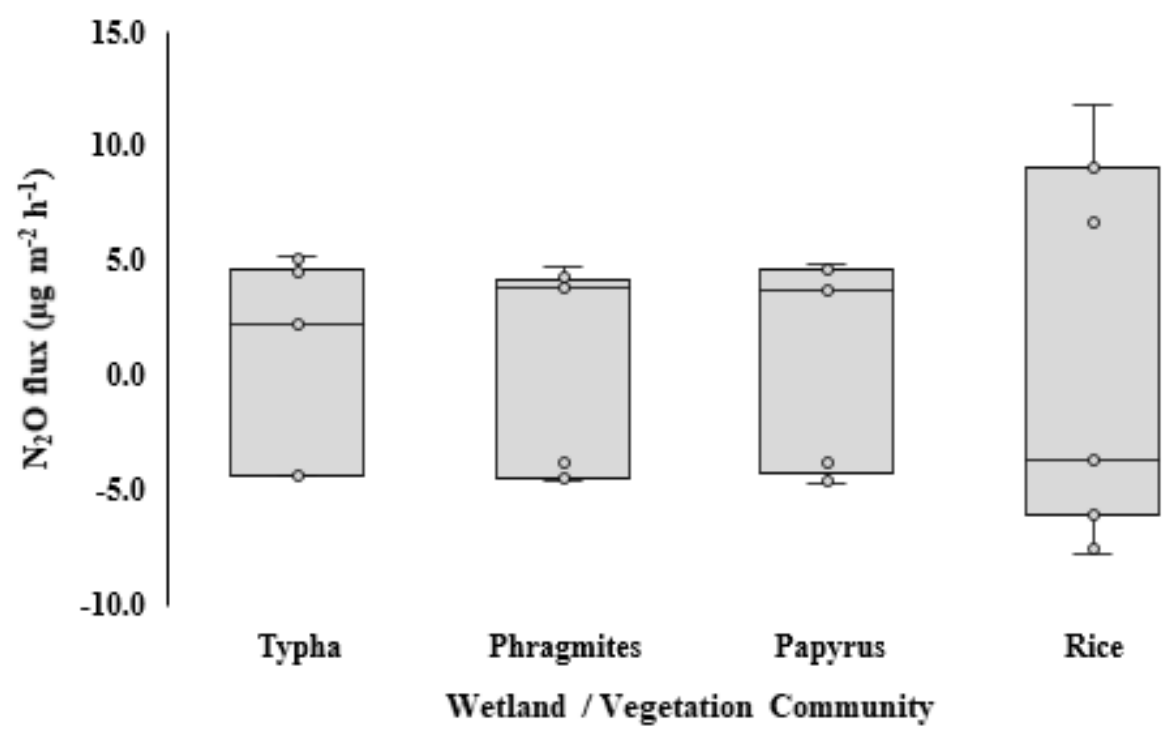

\section{Figure 4}

Comparison of $\mathrm{N} 2 \mathrm{O}$ fluxes from the natural (Papyrus, Typha and Phragmites) and rice paddy (Rice) wetlands during the wet season. Box lines show upper and lower quartiles, while horizontal lines within boxes show median values $(n=72)$. Whiskers extend to the minimum and maximum values. Mean values are not significant across wetlands/vegetation communities $(p>0.05)$ 